\title{
Regional Chromosomal Localization of the Human Gene for Galactose-1-Phosphate Uridyltransferase
}

\author{
N.C. $\operatorname{Sun}^{1}{ }^{*}$, C. R. Y. Sun ${ }^{1}$, and E. H. Y. $\mathrm{Chu}^{2}$ \\ ${ }^{1}$ Biology Division, Oak Ridge National Laboratory, Oak Ridge, Tennessee 37830, USA \\ ${ }^{2}$ Department of Human Genetics, University of Michigan, Medical School, Ann Arbor, \\ Michigan 48104, USA
}

Summary. In the progeny of somatic cell hybrids formed by fusion of human lymphocytes and Chinese hamster mutant cells, a single human chromosome A2 was selectively retained when grown in appropriate medium.

Spontaneous breakage of this chromosome in different hybrid subclones led to the assignment of the gene for galactose-1-phosphate uridyltransferase to the centromeric region of this chromosome (2q11-2q14). This gene is shown to be syntenic to the previously mapped genes for acid phosphatase 1 and malate dehydrogenase 1 .

\section{Introduction}

Somatic cell hybridization between rodent and human cells and subsequent preferential elimination of human chromosomes from the resulting cell hybrids have provided a powerful tool for assigning human genes to individual chromosomes. Taking this approach, it has been possible to assign nearly 100 genes to all human chromosomes except 22 and Y (Kucherlapati and Ruddle, 1976) and the number is increasing. Retaining specific human chromosome(s) in the hybrid progeny was made feasible by a method, linkage ascertainment by fixation, first proposed by Weiss and Green (1967). The technique requires the use of mutant rodent cells lacking the capacity to synthesize a specific enzyme. In appropriate selective medium, the hybrid cell may survive because the rodent mutant phenotype is masked by the wild-type allele on a specific human chromosome which is selectively retained. There should be no ambiguity in regard to the assignment of human genes to the particular chromosomes. The method therefore offers an advantage over the alternative method commonly used, i.e., linkage ascertainment by free segregation (Ruddle, 1972).

In a previous study, we isolated 67 galactose-negative $\left(\mathrm{Gal}^{-}\right)$mutants from survivors after treatment of Chinese hamster lung (V79) cells with 5-bromodeoxy-

* To whom offprint requests should be sent 
uridine and black light (Chu et al., 1972). In contrast to the parental cells, $\mathrm{Gal}^{-}$ mutants could not utilize exogenous galactose or several other hexoses and hexose monophosphates. We postulated that the change from $\mathrm{Gal}^{+}$to $\mathrm{Gal}^{-}$ phenotype in hamster cells could be due to mutations at a regulatory gene locus (Sun et al., 1975), among other possibilities, such as a defect in NADH-coenzyme $Q$ reductase (DeFrancesco et al., 1976). By growing cell hybrids between hamster $\mathrm{Gal}^{-}$mutants and human lymphocytes in medium supplemented with galactose instead of glucose, it was possible to selectively retain the specific human chromosome which complements the $\mathrm{Gal}^{-}$gene. Analysis of three primary interspecific hybrid clones, GJ-1, GM-1, and GJ-3, and 104 secondary clones led to the conclusion that the normal human gene compensating for the hamster mutant $\mathrm{Gal}^{-}$ phenotype, tentatively designated as $\mathrm{Gal}^{+}$-Act, is located on human chromosome A2 (Chu et al., 1975).

Galactose-1-phosphate uridyltransferase (Gal-1-PUT, E.C. 2.7.7.12) catalyzes the conversion of galactose-1-phosphate to glucose-1-phosphate in the Leloir pathway. Transferase deficiency galactosemia in man is inherited as an autosomal recessive and results in a constellation of nutritional failure, liver disease, cataracts, and mental retardation. While the activities of Gal-1-PUT were normal in all hamster $\mathrm{Gal}^{-}$mutants tested, all our hamster-human hybrids that were selected in galactose medium also exhibited, by electrophoresis, the human form of Gal-1-PUT (Sun et al., 1975). It was concluded that the human gene for Gal-1PUT is also located on chromosome A2 (Chu et al., 1975; Sun et al., 1974). This conclusion, however, was contradicted by the assignment of this gene to chromosome A3 as a result of an independent study using the free segregation method in mouse-human cell hybrids (Tedesco et al., 1974). The present study is an attempt to resolve this apparent discrepancy by ascertaining the synteny between the gene for Gal-1-PUT and other genetic loci known to be located on A2. In addition, analysis of different hybrid subclones consisting of spontaneously broken or rearranged A2 delimits the location of this gene to the centromeric region of the chromosome.

\section{Material and Methods}

The hybrids were produced by fusion of galactose-negative mutant cells ( $\mathrm{Ga}$ 1-2) and either human Burkitt lymphoma cells $\left(\mathrm{P}_{3} \mathrm{~J}\right)$ or lymphoblastoid cells (UM-10) derived from a male donor with Lesch-Nyhan syndrome. In the present experiments, the hybrid clone GJ-1, derived from fusion of Ga $\mathrm{I}-2$ and $\mathrm{P}_{3} \mathrm{~J}$, consists of one hamster genome and a single human chromosome $\mathrm{A} 2$, and the hybrid clone GM-1, derived from fusion of Ga1-2 and UM-10, consists of two hamster genomes and a reduced human genome including A2. The methods of cell culture, cell hybridization, and selection of hybrids have been detailed previously (Sun et al., 1974). Air-dried preparations of Colcemid-arrested metaphase cells were stained with a Giemsa-trypsin mixture to reveal the $\mathrm{G}$ bands of the hamster and human chromosomes (Sun et al., 1975).

To prepare cell extraxts, the cells were rinsed twice with Dulbecco's $\mathrm{Ca}, \mathrm{Mg}$-free phosphatebuffered saline and harvested with trypsin-EDTA. The cell pellet was rinsed once with the same saline and extracted by suspending $30 \times 10^{6}$ cells in $1.0 \mathrm{ml}$ of double distilled water, followed by freezing and thawing of the cell suspension three times. The suspension was then centrifuged at $20000 \mathrm{~g}$ for $15 \mathrm{~min}$ at $4^{\circ}$; the supernatant was either used immediately or stored in capped vials over vapor of liquid nitrogen. 
Vertical starch gel electrophoresis for Gal-1-PUT and $\mathrm{ACP}_{1}$ was run at $5 \mathrm{~V} / \mathrm{cm}$ at $4^{\circ}$ for $12 \mathrm{~h}$. For each gel $55 \mathrm{~g}$ Electrostarch was prepared in $400 \mathrm{ml}$ of $5 \mathrm{mM}$ L-histidine $\mathrm{HCl}$ buffer at $\mathrm{pH} 7.0 ; 0.41 \mathrm{M}$ sodium citrate adjusted with concentrated $\mathrm{HCl}$ to $\mathrm{pH} 7.0$ was used as the electrode buffer. Each gel was sliced into two halves and stained for Gal-1-PUT and ACP $_{1}$ respectively. For Gal-1-PUT staining, the gel was flooded with $40 \mathrm{ml}$ of staining solution consisted of $0.1 \mathrm{M}$ Tris- $\mathrm{HCl}$ buffer $(\mathrm{pH} 8.7), 5.0 \mathrm{mM} \mathrm{MgCl} 2-6 \mathrm{H}_{2} 0,6 \mu \mathrm{M}$ glucose-1,6-diphosphate, $1 \mathrm{mM}$ NADP, $0.5 \mathrm{mM}$ UDP-glucose, $0.3 \mathrm{mM}$ phenazine methosulfate, $0.97 \mathrm{mMMTT}$ tetrazolium, 0.5 units $/ \mathrm{ml}$ of phosphoglucomutase, 0.5 units $/ \mathrm{ml}$ of glucose-6-phosphate dehydrogenase, and $1.3 \mathrm{mM}$ galactose-1-phosphate. The gel was incubated at $37^{\circ}$ for 2 to $12 \mathrm{~h}$. The specificity of this staining solution has been confirmed on purified Gal- $\uparrow=P U T$ (Sigma Chemical Co.) and on cell extracts from a human galactosemia patient that showed no Gal-1-PUT activity.

Acid phosphatase activity was localized in the gel by covering the gel with a piece of Whatman $3 \mathrm{MM}$ paper saturated with $10 \mathrm{ml}$ of 4-methyl umbelliferyl-di-hydrogen phosphate, $0.2 \mathrm{mg} / \mathrm{ml}$ of $0.1 \mathrm{M}$ citrate buffer, $\mathrm{pH} 5.5$. After $30 \mathrm{~min}$ of incubation at $37^{\circ}$ the $\mathrm{ACP}_{1}$ activity was visualized as fluorescence under long-wavelength UV light (Swallow et al., 1973).

\section{Results and Discussion}

The identification of "red cell" acid phosphatase (ACP 1 , E.C. 3.1.3.2) in cultured cell lines has provided a useful marker in gene mapping studies (Swallow et al., 1973). The $A C P_{\mathrm{I}}$ gene has been assigned to the distal region of the short arm of human chromosome A2 by deletion mapping (Ferguson-Smith et al., 1973). German and Chaganti (1973) assigned the locus for MN blood groups to the centromeric region of the long arm of human chromosome A2. Mace and Robson (1974) provided supportive evidence for the linkage of genes for $\mathrm{ACP}_{1}$ and the red cell antigen system MNSs. The assignment of the $A C P_{1}$ gene to human chromosome A2 has been further confirmed by the results of somatic cell hybridization studies (Povey et al., 1974).

In this study, two series of human-hamster cell hybrids were constructed between one $\mathrm{Gal}^{-}$mutant, Gal-2, and human lymphocyte cell lines, $\mathrm{P}_{3} \mathrm{~J}$ and UM10. In the first hybrid clone we studied, GJ-1, a single human chromosome A2 was present in addition to complete hamster genome. The concordant presence and absence of this chromosome with human Gal-1-PUT activity suggests that the structural gene for Gal-1-PUT is on this chromosome (Sun et al., 1974). In a subclone of GJ-1, GJ-1(T), most of the long arm of chromosome A2 was missing (2q21-2qter) while the hybrid still expressed the Gal-1-PUT phenotype (Figs. 1 and 2). The second hybrid clone studied, GM-1, was a $2 s$ hybrid with an average of 41 chromosomes per cell, consisting of one complete and one incomplete set of hamster chromosomes and human chromosomes, A2, C11, F20, and G21. In most cells a structurally modified human chromosome A2 was present which lacked the region, $2 \mathrm{q} 21 \rightarrow 2 \mathrm{qter}$, and arose probably as a result of spontaneous deletion. However, both Gal-1-PUT and ACP 1 were expressed (Figs. 2and 3). The positively concordant association of these two markers with chromosome A2 was further demonstrated in 33 of $34 \mathrm{GM}-1$ secondary clones. One remaining secondary clone, GM-1-13, which was also a $2 s$ hybrid, exhibited the activity of $A C P_{1}$ but not Gal-1PUT. Karyotypic analysis of 29 cells of this particular subclone revealed that all cells examined contained a translocated chromosome of spontaneous origin, 



Fig. 1. Giemsa-banding of representative chromosomes: (1) human chromosome A2 from GJ-1; (2) a deleted human chromosome A2 from GJ-1 (T); (3) a deleted human chromosome A2 from GM-1; (4) a translocated chromosome from GM-1-13, a human chromosome $2 p$ was translocated to a hamster chromosome 4q; (5) hamster chromosome 4p from GM-1-13; (6) hamster chromosome 4

Fig. 2. Zymogram showing the activity of Gal-1-PUT from different cell lines: channel 1, Gal-2; channel 2, GJ-1 $\left(\mathrm{G}^{-}\right)$, a galactose-negative subclone from GJ-1; channel 3, GJ-1; channel 4, GJ-1 (T); channel 5, GM-1-13; channel 6, $\mathrm{P}_{3} \mathrm{~J}$

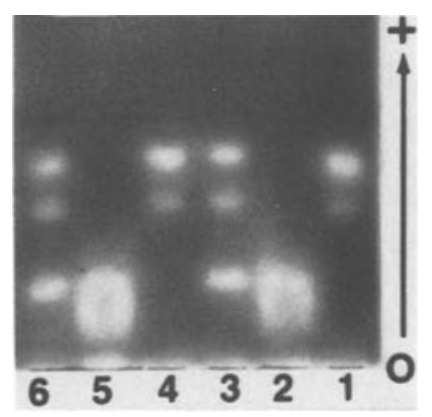

Fig. 3. Zymogram showing the activity of $\mathrm{ACP}_{1}$ from different cell lines: channel 1 , Chinese hamster cell V79; channel 2, UM-10; channel 3, GM-1; channel 4, Gal-2; channel 5, $\mathrm{P}_{3} \mathrm{~J}$; channel 6, GM-1-13

consisting of the short arm of human chromosome A2 and the long arm of hamster chromosome 4 (Fig. 1). The observation that human Gal-1-PUT was not expressed in this clone (Fig. 2) strongly suggests that human gene for Gal-1-PUT is located in the centromeric region of $\mathrm{A} 2$, i.e., $2 \mathrm{q} 11 \rightarrow 2 \mathrm{q} 14$.

The chromosome assignment of Gal-1-PUT locus was reinforced further by studying the segregation pattern of another A2 gene in hamster-human cell hybrids (Chu et al., 1975). The gene, $M D H-1$, for the cytoplasmic form of NAD-dependent malate dehydrogenase (E.C. 1.1.1.37) has been mapped by somatic cell hybridization technique, to human chromosome A2 (Creagan et al., 1974a). In the same group of GM-1 secondary hybrid clones mentioned above, 24 clones were able to utilize galactose, while 10 clones were not. In those clones capable of utilizing galactose, the human forms of Gal-1-PUT (except in GM-1-13), $\mathrm{ACP}_{1}$, and MDH-1 were present; in those clones unable to use galactose, the activities of these human enzymes were absent. This segregation pattern confirms the syntenic relationship 
of these marker genes and their localization on chromosome A2. Furthermore, since the human MDH-1 activity was detected in clone GM-1-13 in which the long arm of A2 is missing, our observation is also consistent with the earlier reports (Creagan et al., 1974b; Hamerton et al., 1975) that this gene is located on the short arm of A2. Particular attention should be given to the expression of constitutive enzymes from hybrids with a $1 s / 1 s$ or $2 s / 1 s$ Chinese hamster/human ratio. GJ-1 is a $1 s$ hybrid in which only Gal-1-PUT is expressed whereas $\mathrm{ACP}_{1}, \mathrm{MDH}-1$, and IDH-1 are not. GM-1 is a $2 s$ hybrid in which Gal-1-PUT, $\mathrm{ACP}_{1}$, and $\mathrm{MDH}-1$ are all expressed except IDH-1 which happens to be located in the missing part of chromosome 2q (Creagan et al., 1974a).

Although somatic cell hybridization has provided a parasexual alternative to the study of genetic linkage in somatic mammalian cells, the event of mitotic crossing-over in mammalian cells has not yet been demonstrated with certainty. Other mechanisms, such as deletion and translocation have to be utilized as a tool for a mapping of genes to specific regions of the chromosomes. Regional localization of genes can be accomplished by either taking advantage of naturally occurring chromosome rearrangements or by selecting subclones in alien addition lines which contain a high frequency of interspecific translocations. This strategy has been successfully exploited by Ricciuti and Ruddle (1973) in the assignment of nucleoside phosphorylase to D14 and phosphoglycerate kinase, hypoxanthine guanine phosphoribosyltransferase and glucose-6-phosphate dehydrogenase to the long arm of the $\mathrm{X}$ chromosome. The present results provide an additional example of regional localization of genes by this strategy.

Acknowledgement. This work has been supported by a grant GB34302 from the National Science Foundation.

\section{References}

Chu, E. H. Y., Chang, C. C., Sun, N. C.: Synteny of the human genes for Gal-1-PUT, ACP, $\mathrm{MDH}-1$, and $\mathrm{Gal}^{+}$-Act and assignment to chromosome 2. Human Gene Mapping 2, Rotterdam Conference (1974), Birth Defects Original Article Series, Vol. 11, No. 3, pp. 103-106 (1975)

Chu, E. H. Y., Sun, N. C., Chang, C. C.: Induction of auxotrophic mutations by treatment of Chinese hamster cells with 5-bromodeoxyuridine and black light. Proc. nat. Acad. Sci. (Wash.) 69, 3459-3463 (1972)

Creagan, R. P., Carritt, B., Chen, S., Kucherlapati, R., McMorris, F. A., Ricciuti, F., Tan, Y. H., Tischfield, J. A., Ruddle, F. H.: Chromosome assignments of genes in man using mousehuman somatic cell hybrids: Cytoplasmic isocitrate dehydrogenase (IDH 1) and malate dehydrogenase (MDH 1) to chromosome 2. Amer. J. hum. Genet. 26, 604-613 (1974a)

Creagan, R. P., Carritt, B., Chen, S., Kucherlapati, R., McMorris, F. A., Ricciuti, F., Tan, Y. H., Tischfield, J. A., Ruddle, F. H.: Confirmation of the synteny of the human genes for cytoplasmic isocitrate dehydrogenase and cytoplasmic malate dehydrogenase and assignment to chromosome 2. Human Gene Mapping, New Haven Conference (1973), Birth Defects Original Article Series, Vol. 10, No. 3, pp. 79-82 (1974b)

DeFrancesco, L., Scheffler, I. E., Bissell, M. J.: A respiration-deficient Chinese hamster cell line with a defect in NADH-coenzyme Q reductase. J. biol. Chem. 251, 4588-4595 (1976)

Ferguson-Smith, M. A., Newman, B. F., Ellis, P. M., Thomson, D. M. G., Riley, I. D.: Assignment by deletion of human red cell acid phosphatase gene locus to the short arm of chromosome 2. Nature (New Biol.) 243, 271-274 (1973) 
German, J., Chaganti, R. S. K.: Mapping human autosomes: Assignment of the MN locus to a specific segment in the long arm of chromosome No. 2. Science 182, 1261-1262 (1973)

Hamerton, J. L., Mohandas, T., McAlpine, P. J., Douglas, G. R.: Assignment of three human gene loci to regions of chromosome 2. Human Gene Mapping 2, Rotterdam Conference (1974), Birth Defects Original Article Series, Vol. 11, No. 3, pp. 176-178 (1975)

Kucherlapati, R. S., Ruddle, F. H.: Advances in human gene mapping by parasexual procedures. Prog. Med. Genet. 1, 121-144 (1976)

Mace, M., Robson, E. B.: Linkage data on $\mathrm{AcP}_{1}$ and MNSs. Human Gene Mapping, New Hafen Conference (1973), Birth Defects Original Article Series, Vol. 10, No. 3, pp. 123-125(1974)

Povey, S., Swallow, D. M., Bobrow, M., Craig, I., van Heyningen, V.: Probable assignment of the locus determining human red cell acid phosphatase $\mathrm{ACP}_{1}$ to chromosome 2 using somatic cell hybrids. Ann. hum. Genet. 38, 1-5 (1974)

Ricciuti, F., Ruddle, F. H.: Assignment of nucleoside phosphorylase to D14 and localization of X-linked loci in man by somatic cell genetics. Nature (New Biol.) 241, 180-182 (1973)

Ruddle, F. H.: Linkage analysis using somatic cell hybrids. Adv. hum. Genet. 3, 173-235(1972)

Sun, N. C., Chang, C. C., Chu, E. H. Y.: Mutant hamster cells exhibiting pleiotropic effect on carbohydrate metabolism. Proc. nat. Acad. Sci. (Wash.) 72, 469-473 (1975)

Sun, N. C., Chang, C. C., Chu, E. H. Y.: Chromosome assignment of the human gene for galactose-1-phosphate uridyltransferase. Proc. nat. Acad. Sci. (Wash.) 71, 404-407 (1974)

Swallow, D. M., Povey, S., Harris, H.: Activity of the red cell acid phosphatase locus in other tissues. Ann. hum. Genet. 37, 31-38 (1973)

Tedesco, T. A., Diamond, R., Orkwiszewski, K. G., Boedecker, H. J., Croce, C. M.: Assignment of the human gene for hexose-1-phosphate uridyltransferase to chromosome 3. Proc. nat. Acad. Sci. (Wash.) 71, 3483-3486 (1974)

Weiss, M. C., Green, H.: Human-mouse hybrid cell lines containing partial complements of human chromosomes and functioning human genes. Proc. nat. Acad. Sci. (Wash.) 58, 1104-1111 (1967)

Received February 2, 1977 